\title{
A Comparative Analysis between Shariah Audit and Shariah Review in Islamic Banks in Malaysia: Practitioners' Perspective
}

\author{
Mohd Rushdan Yasoa' ${ }^{1}$, Wan Amalina Wan Abdullah ${ }^{2}$, Wan Anisah Endut ${ }^{2}$ \\ 1 Faculty of Entrepreneurship and Business, Universiti Malaysia Kelantan \\ 2 Faculty of Business and Management, Universiti Sultan Zainal Abidin \\ rushdan.y@umk.edu.my, amalina@unisza.edu.my, wanisah@unisza.edu.my \\ Tel: 019-7759795
}

\begin{abstract}
This paper compares Shariah audit and Shariah review in Islamic banks in Malaysia based on reporting structure, independence, the scope of duties, technology used, guideline and methodology, coverage period, and officers' qualification. The study employs a qualitative method by utilizing semistructured interviews with nine (9) key industry players. Data gathered from a series of interviews have been transcripted and analyzed using Atlas.ti. This study uncovers that Shariah review and Shariah audit have apparent differences and play their roles as a second and third line of defense, respectively, that eventually could provide a stimulus to Shariah governance and strengthen market confidence.
\end{abstract}

Keywords: Shariah audit, Shariah review, Islamic banks, qualitative method

eISSN: 2398-4287@ 2020. The Authors. Published for AMER ABRA cE-Bs by e-International Publishing House, Ltd., UK. This is an open access article under the CC BYNC-ND license (http://creativecommons.org/licenses/by-nc-nd/4.0/). Peer-review under responsibility of AMER (Association of Malaysian Environment-Behaviour Researchers), ABRA (Association of Behavioural Researchers on Asians) and cE-Bs (Centre for Environment-Behaviour Studies), Faculty of Architecture, Planning \& Surveying, Universiti Teknologi MARA, Malaysia.

DOI: https://doi.org/10.21834/ebpj.v5i14.2208

\subsection{Introduction}

Shariah compliance is considered as a backbone to the Islamic banking industry. Apart from the Shariah Committee (ShC) as a corporate governance mechanism in the Islamic banks that play their role in overseeing the products and services to be a Shariah-compliant, Shariah review and Shariah audit play their role simultaneously to achieve the same objective. The establishment of these Shariah organs is primarily due to ensuring the Islamic financial institutions (IFIs), including Islamic banks, fulfill the Shariah requirement (Bahari \& Bahrudin, 2016).

According to Bank Negara Malaysia (BNM), Shariah review "refers to a function that conducts regular assessment on the compliance of the operations, business, affairs, and activities of the IFI with Shariah requirements." At a minimum, the Shariah review function must identify, assess, and monitor the compliance of the IFl's business operations and activities with Shariah. The team should report to the Board of Directors (BOD), ShC, and senior management regularly on Shariah non-compliance (SNC) issues and findings as well as the latest developments in legal and regulatory requirements in Islamic finance.

In the meantime, Shariah audit refers to "a function that provides an independent assessment on the quality and effectiveness of the IFI's internal control, risk management systems, governance processes as well as the overall compliance of the IFI's operations, business, affairs, and activities with Shariah" (Bank Negara Malaysia, 2019). According to Shariah Governance, Shariah audit function at least must establish an audit methodology to assess the risk profile, generate an audit plan, establish documented audit programs and communicate results to the BOD and ShC through an audit report.

Even though BNM provides a series of guidelines and policy documents to industry players, many internal Shariah auditors and Shariah review officers are still unclear about their functions. Many of them only understand the differences conceptually, but they are still ambiguous in operationalization (Yazkhiruni, Nurmazilah, \& Haslida, 2018). They further argue that the Shariah auditing process

eISSN: 2398-4287@ 2020. The Authors. Published for AMER ABRA cE-Bsby e-International Publishing House, Ltd., UK. This is an open access article under the CC BYNC-ND license (http://creativecommons.org/licenses/by-nc-nd/4.0/). Peer-review under responsibility of AMER (Association of Malaysian Environment-Behaviour Researchers), ABRA (Association of Behavioural Researchers on Asians) and cE-Bs (Centre for Environment-Behaviour Studies), Faculty of Architecture, Planning \& Surveying, UniversitiTeknologi MARA, Malaysia.

DOI: https://doi.org/10.21834/ebpj.v5i14.2208 
was ineffective due to repetitious tasks between Shariah audit and Shariah review procedures. Thus, comparing the roles and functions between these two organs rooted from primary sources seems important as endeavored in this study.

\subsection{Literature Review}

AAOIFI, through GSIFI No 2, describes that Shariah review plays a vital role in ensuring all activities in Islamic banks adhere to Shariah rules and regulations as suggested in the fatwa, rulings, and guidelines issued by Shariah Supervisory Board (SSB) (AAOIFI, 2015). According to this standard, an effective Shariah review will deliberate and cooperate with advisors such as external auditor and shall provide a report concomitantly to the $\mathrm{ShC}$ and Management.

The Shariah review function is essential to adequately expound the Shariah governance practice (Masruki, Mohd Hanefah, \& Ab. Wahab, 2018). In order to build a comprehensive Shariah-compliant environment in their operation and business activities, IFls are expected to outline and perform the function of Shariah Review (Bank Negara Malaysia, 2011). The Shariah review department usually acts as a referral point for the internal audit department to confirm and clarify Shariah issues (Yazkhiruni et.al, 2018).

Muhamad Sori, Mohamad, \& Shah (2015) disclose that the Shariah review officer obliges to examine the operation flow and investigates SNC's incidence. Shariah review officer will visit all branches and divisions and perform relevant examinations. If the Shariah review function found any SNC incidence, they will provide feedback and require the respective branch or department to rectify the noncompliance. However, it is more towards an internal consultative nature than audit findings, which are more towards reprimanding or penalizing non-compliance.

Alwi (2007) asserts that, in general, Shariah review has been used by IFIs to ensure Shariah compliance. However, he feels that a Shariah review process is not sufficient since its scope is somewhat limited. Thus, he suggests the Shariah audit as a more appropriate tool to ensure Shariah compliance. It covers a broader scope of examination, including the technology supporting the operations, operational processes, and the people involved in the critical areas of risk.

At present, studies specifically comparing Shariah audit and Shariah review tend to be very limited due to the nature of this area. Thus, this study will add a piece of new knowledge to the existing literature given the fact of the scarcity of the Shariah audit literature. Previous studies tend to discuss the competency of the Shariah auditor (Alam, Hassan, \& Ferdous, 2017; Mohd Ali, Shafii, \& Shahimi, 2020) human capital development (Shafii, Salleh, Mohd Hanefah, \& Jusoff, 2013) Shariah audit practice (Ahmad, 2017; Hisham Kamaruddin \& Mohd Hanefah, 2017; Rashid, Abdul Hamid, Mohamad Sidek, Wan Abdullah, \& Mohd Ali, 2017), the perceptions towards Shariah audit (Mohd Ali, Shahimi, \& Shafii, 2018; Shafii, Zainal Abidin, \& Salleh, 2015), and Shariah audit model (Shafii et al., 2015).

Besides, this study is different from past studies because many previous studies use a questionnaire survey method to gather data. According to Queirós, Faria, \& Almeida (2017), the reliability of data from the survey is very much dependent on its structure and the accurate answers provided by their respondents. On the contrary, the current study uses a qualitative method to collect data by employing semi-structured interviews.

Thus, this paper aims to fill this gap by analyzing the differences between Shariah audit and Shariah review based on practitioners' views. Even though prior scholars have continuously discussed this issue, this paper has its uniqueness in that it gauges new data through a qualitative approach that would contribute to new knowledge specifically related to this area.

\subsection{Methodology}

A qualitative approach has been used in this study by employing an in-depth interview. By utilizing semi-structured questions during the interview sessions, it will open up free discussion between the researcher and participants in order to gauge as many as possible an uncover differences between Shariah audit and Shariah review.

In this study, the selection of respondents is based on purposive sampling. According to Engel \& Schutt (2014), a purposive sample is appropriate to be used when the selected sample is based on the established objective and focuses on a group of experts such as internal auditor and Shariah officer. Even though the sample size is relatively small, which consists of 9 interviewees only, it is considered normal in a qualitative study because they are selected based on the criteria that provide useful information on the phenomenon under investigation (Creswell \& Poth, 2018). Besides, the mix of the Shariah auditors, the heads of the Shariah audit, and the other industry players such as chief Shariah officer and ShC member would provide fruitful details on the subject matters (Mohd Ali, Mohamed, Shahimi, \& Shafii, 2015).

The respondents were coded based on the position and types of groups. This approach certainly is to keep the confidentiality of the data. Finally, the interviewees for this study is presented in Table 1 as follows:

Table 1: Interviewees For The Study

\begin{tabular}{lllc}
\hline \multicolumn{1}{c}{ Types of Group } & \multicolumn{1}{c}{ Position } & Respondent Code & Total \\
\hline \multirow{3}{*}{ Full-fledged Islamic Banks (FFIB) } & Chief Shariah Officer & CSO-FFIB & 1 \\
& Head of Shariah Audit & HSA-FFIB & 1 \\
& Head Office and Shariah Audit & HOSA-FFIB & 1 \\
\multirow{2}{*}{ Islamic Banking Subsidiaries (IBS) } & Head of Islamic Banking Audit & HIBA-IBS & 1 \\
& Senior Director of Islamic Business Unit & SDIBU-IBS & 1 \\
& Head of Shariah Audit & HSA-DFI & 1 \\
Development Financial Institutions (DFI) & Shariah Auditor & SA-DFI & 1 \\
& Shariah Committee Member & ShC-DFI & 1 \\
Islamic Windows (IW) & Head of Shariah Audit & HSA-IW & 1 \\
\hline
\end{tabular}


The study acknowledges the limitation since it does not obtain the samples from the Shariah review officer due to the difficulties in getting the data.

Before the analysis can be performed, the verbatim transcription was accomplished for all interview sessions by employing the Computer Assisted Qualitative Design Analysis Software (CAQDAS), namely Atlas.ti version 8.0. This software is used to facilitate the process of transcribing the interview audio and data coding. Then, the researcher develops relevant codes from this transcription and generates appropriate themes that eventually presented in the findings section.

\subsection{Findings}

\subsection{Roles of Shariah audit and Shariah review}

It is essential to define both of them according to their roles. SDIBU-IBS compares these roles accordingly as follows:

"...The role of Shariah review is more less what is the role performed by the compliance department in confirming that the bank at all times complies with the Shariah requirement. However, from an audit perspective, we audit post-event, whereby the business has done, the project has completed. Hence, Shariah review should be before, and Shariah audit should be after..." (SDIBU-IBS).

Based on the above statement, it is evident that the Shariah review focuses on pre-event and, on the contrary, Shariah audit centers on post-event. On the contrary, the head of Shariah audit from DFI pinpoints a different perspective whereby he remarks that Shariah auditor focuses more on the internal control aspect as he mentions:

"...Shariah reviewer checks whether the bank is complying with Shariah principles. Meanwhile, Shariah auditors focus more on internal control, whether internal control is strong enough to ensure no SNC issues..."(HSA-IW).

This view is actually in line with Shafii et al. (2014) contend that Shariah auditors should be equipped with knowledge of internal control systems of an Islamic bank.

\subsection{Guideline and methodology}

In terms of the guideline, HIBA-IBS states that the Shariah audit follows guidelines provided by Shariah Governance Framework (SGF) and Institute of Internal Auditors (IIA) in performing its role. However, there is neither specific guideline nor standard provided for Shariah review as he remarks:

"...Shariah audit is a profession. Whereas Shariah review is a function, and they are not governed by standards because there is no standard provided for them (Shariah review). So, they execute the process in achieving the objectives based on what they feel good. On the contrary, while executing the process, we (Shariah audit) are abiding by certain standards..."(HIBA-IBS).

Table 2: Differences between Shariah audit and Shariah review

\begin{tabular}{lll}
\hline \multicolumn{1}{c}{ Features } & \multicolumn{1}{c}{ Shariah audit } & \multicolumn{1}{c}{ Shariah review } \\
\hline $\begin{array}{l}\text { Role } \\
\text { Guidelines and methodology }\end{array}$ & Assurance and Internal Control, Post-event & Compliance, Pre-event \\
IIA, SGF2011, SGPD2019 & $\begin{array}{l}\text { SGF2011, SGPD2019, own guideline } \\
\text { (domestically recognised) }\end{array}$ \\
& $\begin{array}{l}\text { Much wider, covers overall processes (micro } \\
\text { and macro), covers whole transactions and } \\
\text { entities }\end{array}$ & $\begin{array}{l}\text { Much narrow, focuses on micro aspect only } \\
\text { and limited to Shariah compliance function }\end{array}$ \\
Technology & T-mate, ACL software & Select manually \\
Independency & Independent party & Part of the management \\
Ability to audit/review ShC & Yes & No \\
Reporting line & Report directly to BAC, indirectly to ShC & $\begin{array}{l}\text { Report directly to ShC, report administrative } \\
\text { matters to BOD/management }\end{array}$ \\
Qualification & Internal auditors who have the requisite & $\begin{array}{l}\text { Officers qualified may include officers with } \\
\text { Shariah qualification. }\end{array}$ \\
\hline
\end{tabular}

Concerning methodology employed in executing their tasks, Shariah auditor entirely relies on SGF, standards issued, and circulated by BNM and IIA standard. HIBA-IBS again underlines that:

"...We (Shariah auditor) systematically conduct our audit according to standard, whereas they (Shariah review) maybe have a certain level based on their standard, I mean domestically recognized. However, if they bring their methodology to other banks, it might be different. Nevertheless, for Shariah audit, wherever they go, the standard will be the same..."(HIBA-IBS).

In this regard, HOSA-FFIB opines an identical understanding in describing the methodology used by the Shariah review based on her real experience in conducting an audit on Shariah review, as she notes:

"...We (Shariah auditor) have experience in auditing Shariah review. However, it is a bit bias if I say that the Shariah audit is better in terms of working papers and substance because when we audit Shariah review, sometimes the document is not available. The way they conduct the review may be thorough, but they cannot provide the evidence even though the finding is stated clearly in the report ..." (HOSA-FFIB).

Therefore, it is evident that the Shariah audit has a more systematic and structured methodology, guideline, as well as specific planning as compared to Shariah review in performing its roles.

\subsection{Scope of duties}

Regarding the scope of duties, HOSA-FFIB proposes that there should be a discussion between Shariah audit and Shariah review to 
reduce the redundancy of the scope of duties for both parties. In this regards, she mentions that:

"...In terms of scope, we (Shariah audit) have a regular discussion with Shariah review. If we want to do any planning, especially annual planning, we will ask Shariah review to be present first because they have done their analysis normally. This discussion is to avoid any overlapping..."(HOSA-FFIB).

The abovementioned statement is supported by Abd Rahman et al. (2018), whereby in preparing the Shariah audit plan, Shariah auditor may also get a piece of advice from other internal Shariah organs such as Shariah risk and Shariah review.

In terms of the scope of duties, HIBA-IBS claims that the scope for Shariah review is much narrow, and it just focuses on the micro aspect only since it is limited to Shariah compliance function as he remarks:

"...The scope for Shariah review they are looking at the product, they are looking at the process, but they are not looking at the entity. They focus more on micro and limit their scope to Shariah compliance and Shariah requirement compliances only..." (HIBA-IBS).

He further explains that unlike Shariah review, Shariah audit looks beyond the Shariah review scope. For instance, their scope extends to how to mitigate the credit risk, operational risk, market risk on the activity, and focusing on Islamic as well.

\subsection{Technology}

Another difference between Shariah audit and Shariah review could be identified through technology employed in executing their roles. Some interviewees argued that the Shariah audit is technology savvy because they employ the latest software in performing Shariah audit tasks. SA-DFI claims that:

"...the Shariah review department in this bank does not use technology in their review, but for us (Shariah audit), we do have IIA. In IIA, they have sorts of T-mate and ACL. We use that as part of our technology to do sampling to find exceptions on Shariah. However, Shariah review still uses manual..." (SA-DFI).

In line with the above argument, Ayedh, Mahyudin, Abdul Samat, \& Muhamad Isa, (2019) propose that the banks should ensure employees who are in charge of any function related to Shariah (i.e., Shariah review, Shariah audit, and Shariah risk management) to have basic knowledge on IT and information system. Continuous training for IFIs' employees, covering the information system, and ICS issues related to Shariah compliance should also be considered by management.

\subsection{Independency and Reporting Line}

One of the critical aspects that distinguish between Shariah audit and Shariah review is independence as well as the reporting line. Interestingly, ShC-DFI emphasizes the uniqueness of the Shariah audit as they can audit the ShC even though indirectly they (Shariah audit) need to report to the ShC as well, as she describes:

"...Shariah review cannot check the ShC, but the Shariah audit can audit the ShC. It shows that Shariah auditor is more likely to be independent than Shariah review because they can still audit the ShC even though they have to submit an audit report to them..."(ShC-DFI).

In terms of reporting line, as stated clearly in SGPD 2019, the Shariah audit will report to Board Audit Committee (BAC) and Shariah review needs to submit a report to ShC respectively (Bank Negara Malaysia, 2019). In this juncture, most of the interviewees agree that their institutions follow this practice accordingly except few interviewees highlight slightly different, especially from the operational aspect, for instance:

"...In terms of reporting is also different. The Shariah audit reports directly to BAC. In contrast, Shariah review, they report to ShC, but at the same time, they report the administrative matters to the board. However, Shariah audit still reports to ShC indirectly..."(HOSA-FFIB).

In a nutshell, there are apparent differences between reporting structure for Shariah audit and Shariah review, respectively, as per Shariah Governance 2019. However, some interviewees reported that there is an additional internal reporting line structure to strengthen the governance, such as from Shariah review to the management (dotted line) as well as to the BOD.

\subsection{Qualification of officers}

According to Bank Negara Malaysia (2019), the Shariah audit must be performed by internal auditors, who have the requisite knowledge on Shariah requirements applicable to Islamic financial business. However, according to (HD-Edbiz, 2017), background in either Shariah or auditing alone is not sufficient in conducting the Shariah audit. Shariah auditors must also be qualified professionals in Islamic financial and commercial relations (muamalat).

On the other hand, Shariah review should be conducted by a qualified Shariah officer who holds at least a degree in Shariah, which includes study in Usul Fiqh (the origin of Islamic law) and Fiqh Muamalat (Islamic transaction/commercial law). Considering this guideline, an ShC from DFI confirms the practice at her bank by highlighting that:

"...Based on SGF, the Shariah review must possess a background in Shariah. It is not acceptable for an accounting background to do the Shariah review. However, Shariah audit can be from Shariah degree background..."(DFI-SHC).

The present finding is also supported by Abu Samah \& Hassan (2014) found that $85 \%$ of the officer conducting a Shariah review holds a bachelor's degree in Shariah. In the meantime, Hassan et al. (2013) confirm the current findings by stating that around $88.5 \%$ of their respondents were internal auditors that conduct Shariah audit exercise as compared to only $17.9 \%$ of Shariah officers are conducting Shariah audit exercise.

\section{Conclusion}

This paper compares and contrasts between Shariah audit and Shariah review in Islamic banks in Malaysia. By utilizing semi-structured interviews with nine (9) key industry players, we analyze the differences in terms of the role, guideline and methodology, scope of duties, technology, independence and reporting line, and qualification of the officers.

Fruitful findings have been revealed from this study whereby the majority of the interviewees provide a clear insight with regards to 
differences between these two components. In terms of reporting lines, most of them state that Shariah audit reports directly to the BOD and indirectly to the ShC. Whereas Shariah review reports directly to $\mathrm{ShC}$ and, at the same time, administratively reports to management. Thus, some interviewees argued that the Shariah audit is much better in terms of independency level compared to Shariah review as they (Shariah audit) do not involve and reported to the management. Besides, the scope of duties of the Shariah audit is much broader because it does cover not only the Shariah compliance aspect but also operational aspects, including internal controls.

Concerning the technology used, some interviewees claim that the Shariah audit at their institutions tends to employ special software to facilitate audit works. On the contrary, they claim that the Shariah review relies on the manual approach, especially in choosing their samples. Regarding the methodology used, the Shariah review tends to focus on the Shariah compliance aspect only. In contrast, the Shariah audit covers the operational aspect as well. Finally, most of the interviewees state that the Shariah audit team must have the workforce with audit skills and experience regarding the qualification of officers. Meanwhile, Shariah review strictly follows what has been stipulated in the guideline whereby holding a degree in Shariah is a must to conduct Shariah review.

As for recommendations to strengthen the situation, the Shariah review team needs to widen its scope of duties by focusing not only on the Shariah compliance aspect but also on the operational aspect. They should also consider employing technology in their sampling procedure to increase the numbers of review samples. Eventually, the investigation of SNC cases would be more effective.

In a nutshell, Shariah review and Shariah audit play their roles respectively by giving assurance to the stakeholders that all businesses and operations of the Islamic banks comply with Shariah principles. By having a clear function of Shariah audit and Shariah review, the Islamic banks can effectively mitigate SNC risks. This scenario could eventually provide a stimulus to improve governance and strengthen market confidence. Future research may consider samples from the Shariah review team, external auditor, and regulator to produce more robust and all-inclusive findings.

\section{References}

AAOIFI. (2015). Accounting, Auditing and Governance Standards. Manama, Bahrain: Dar AlMaiman.

Abu Samah, Z., \& Hassan, R. (2014). Empirical study on the understanding of Shariah review by Islamic banks in Malaysia. In Islamic Business Management Conference (pp. 1-7).

Ahmad, S. (2017). Practice of Shariah Audit in Islamic Banking in Pakistan. Journal of Islamic Economics, Banking and Finance, 13(2), $102-127$.

Alam, T., Hassan, T., \& Ferdous, K. (2017). Competency of Shariah auditors: Issues and challenges in Pakistan. Journal of Internet Banking and Commerce, 22(2), $1-$ 12. https://doi.org/10.12816/0024798

Alwi, M.(2007). A Mini Guide to Shariah Audit for Islamic Financial Institution - A Primer. Kuala Lumpur: CERT Publications.

Ayedh, A. M., Mahyudin, W. A., Abdul Samat, M. S., \& Muhamad Isa, H. H. (2019). The integration of Shariah compliance in information system of Islamic financial institutions: Qualitative evidence of Malaysia. Qualitative Research in Financial Markets. https://doi.org/10.1108/QRFM-05-2017-0042

Bahari, N. F., \& Bahrudin, N. A. (2016). Shariah Governance Framework: The roles of Shariah review and Shariah auditing. In Proceeding of the 3rd International Conference on Management \& Muamalah (pp. 375-381).

Bank Negara Malaysia. (2011). Shariah governance framework for Islamic financial institutions. Malaysia. https://doi.org/10.1007/s13398-014-0173-7.2

Bank Negara Malaysia. Shariah Governance Policy Document (2019). https://doi.org/10.1016/S0141-6359(03)00004-7

Creswell, J. W., \& Poth, C. N. (2018). Qualitative Inquiry and research design choosing among five approaches (Fourth Edi). Thousand Oaks, Calif.: SAGE Publications Inc. https://doi.org/10.2307/1523157

Engel, R. J., \& Schutt, R. K. (2014). Fundamental of social work research (Second). Boston, USA: SAGE Publications Inc.

Hassan, R., Ariffin, M., Othman, A. A., Napiah, M. D. M., Omar, M. N., Yusoff, A., ... Zaharim, A. (2013). Survey on implementation of internal Shariah Compliance function in Malaysian Islamic banks and Takaful companies. Recent Advances in Management, Marketing and Finances, 101-107.

HD-Edbiz. (2017). State of Shariah governance in Islamic finance. Global Islamic Finance Report 2017.

Hisham Kamaruddin, M. I., \& Mohd Hanefah, M. (2017). Enhancing Shariah audit practices in Islamic financial institutions in Malaysia. Journal of Modern Accounting and Auditing, 13(11), 457-470. https://doi.org/10.17265/1548-6583/2017.11.001

Masruki, R., Mohd Hanefah, M., \& Ab. Wahab, N. (2018). Shariah Supervisory Board (SSB) and Performance of Islamic Banks in Malaysia. International Journal of Engineering \& Technology, 7(3.25), 710-714. Retrieved from www.sciencepubco.com/index.php/IJET

Mohd Ali, N. A., Mohamed, Z. M., Shahimi, S., \& Shafii, Z. (2015). Competency of Shariah auditors in Malaysia : issues and challenges. Journal of Islamic Finance, 4(1), 22-30. https://doi.org/10.12816/0024798

Mohd Ali, N. A., Shafii, Z., \& Shahimi, S. (2020). Competency model for Shari'ah auditors in Islamic banks. Journal of Islamic Accounting and Business Research, 11(2), 377-399. https://doi.org/10.1108/JIABR-09-2016-0106

Mohd Ali, N. A., Shahimi, S., \& Shafii, Z. (2018). Knowledge, Skills and Characteristics Requirements for Shariah Auditors. Asian Journal of Accounting and Governance, 9(1), 181-200. 
Muhamad Sori, Z., Mohamad, S., \& Shah, M. I. (2015). Shariah governance practices in Malaysian Islamic financial institutions. SSRN Electronic Journal, (December), 1-15. https://doi.org/http://doi.org/10.2139/ssrn.2579174

Queirós, A., Faria, D., \& Almeida, F. (2017). Strengths and limitations of qualitative and quantitative research methods. European Journal of Education Studies, 3(9), 369387. https://doi.org/10.5281/zenodo.887089

Rashid, A. A., Abdul Hamid, M., Mohamad Sidek, A. S., Wan Abdullah, W. M. T., \& Mohd Ali, I. (2017). Shari'ah auditing: A review of shari'ah audit practices in Islamic financial institution (IFIs). SHS Web of Conferences 36, 00019, 1-5.

Shafii, Z., Salleh, S., Mohd Hanefah, H. M., \& Jusoff, K. (2013). Human capital development in Shariah audit. Middle-East J. Sci Res (Research in Contemporary Islamic Finance and Wealth Management), 13(6), 28-34. https://doi.org/10.5829/idosi.mejsr.2013.13.1878

Shafii, Z., Salleh, S., Zakaria, N., Mohd Hanefah, M., Mohd Ali, N. A., \& Yunanda, R. A. (2014). Shariah audit certification contents: Views of regulators, Shariah committee, Shariah reviewers and undergraduate students. International Journal of Economics and Finance, 6(5), 210-219. https://doi.org/10.5539/ijef.v6n5p210

Shafii, Z., Zainal Abidin, A., \& Salleh, S. (2015). Integrated Internal-External Shariah Audit Model : A Proposal towards the Enhancement of Shariah Assurance Practices in Islamic Financial Institutions (WP\#1436-07). Jeddah. https://doi.org/RePEc:ris:irtiwp:1436_007

Yazkhiruni, Y., Nurmazilah, M., \& Haslida, A. H. (2018). A review of Shariah auditing practices in ensuring governance in Islamic financial institution (IFIs)-A preliminary study. Advances in Social Sciences Research Journal, 5(7), 196-210. https://doi.org/10.14738/assri.57.4873 